\title{
Mutants of Alcaligenes eutrophus Defective in Autotrophic Metabolism
}

\author{
Bernhard Schink and Hans Günter Schlegel \\ Institut für Mikrobiologie der Gesellschaft für Strahlen- und Umweltforschung mbH München \\ und Institut für Mikrobiologie der Universität Göttingen, \\ Grisebachstr. 8, D-3400 Göttingen, Federal Republic of Germany
}

\begin{abstract}
Forty-four mutants of Alcaligenes eutrophus $\mathrm{H} 16$ were isolated which grew poorly or not at all under autotrophic conditions. Four types were characterized with respect to their defects and their physiological properties. One mutant lacked both enzymes specific for autotrophic $\mathrm{CO}_{2}$ fixation, another one lacked both hydrogenases, and two mutants lacked either the membrane-bound or the soluble hydrogenase. Comparing the results of studies on these mutant types, the following conclusions were drawn: the lack of each hydrogenase enzyme could be partially compensated by the other one; the lack of membrane-bound hydrogenase did not affect autotrophic growth, whereas the lack of the soluble hydrogenase resulted in a decreased autotrophic growth rate. When pyruvate as well as hydrogen were supplied to the wild-type, the cell yield was higher than in the presence of pyruvate alone. Mutant experiments under these conditions indicated that either of both hydrogenases was able to add to the energy supply of the cell. Only the soluble hydrogenase was involved in the control of the rate of hydrogen oxidation by carbon dioxide; the mutant lacking this enzyme did not respond to the presence or absence of $\mathrm{CO}_{2}$. The suppression of growth on fructose by hydrogen could be mediated by either of both hydrogenases alone.
\end{abstract}

Key words: Hydrogenase - Regulation $-\mathrm{CO}_{2}$-effect $-\mathrm{H}_{2}$-effect - Mixotrophy - Reverse electron flow Alcaligenes eutrophus.

In aerobic hydrogen bacteria molecular hydrogen is activated by hydrogenases for energy generation and for autotrophic $\mathrm{CO}_{2}$-reduction. With respect to their hydrogenase patterns, three groups of hydrogen bacteria can so far be distinguished: 1. Both the soluble NAD-reducing hydrogenase (hydrogendehydrogenase or $\mathrm{H}_{2}: \mathrm{NAD}^{+}$oxidoreductase, $\mathrm{EC}$ 1.12.1.2) as well as a membrane-bound hydrogenase, which is not able to reduce pyridine nucleotides, are present in Pseudomonas saccharophila (Vishniac and Trudinger, 1962), Alcaligenes ruhlandii (Bone et al., 1963), Alcaligenes eutrophus (Wittenberger and Repaske, 1961), and Alcaligenes eutrophus H16 (Eberhardt, 1966; Pfitzner et al., 1970). 2. Only a membrane-bound hydrogenase is present in Pseudomonas facilis (Atkinson and McFadden, 1954), Paracoccus denitrificans (Kühnemund, 1971) and other pseudomonads and coryneform bacteria (Schneider and Schlegel, 1977). 3. Only an NAD-reducing hydrogenase, which is soluble or loosely bound to the membranes, is present in Nocardia opaca $1 \mathrm{~b}$ (Aggag and Schlegel, 1973, 1974), and other strains of Nocardia autotrophica (Ecker, 1977).

Bacteria containing only a membrane-bound hydrogenase are dependent on reverse electron transport for NAD reduction. Experimental evidence for reverse electron transport in membranes of $A$. eutrophus has been reported (Ishaque and Aleem, 1970).

In $A$. eutrophus hydrogen and hydrogenases are involved in regulatory phenomena. One regulatory mechanism concerns the enhancement of hydrogen oxidation by $\mathrm{CO}_{2}$. In intact cells, the rate of $\mathrm{H}_{2}+\mathrm{O}_{2}$ consumption is $3-4$ times higher in the presence of $\mathrm{CO}_{2}$ than in its absence (Schlegel and Bartha, $1961 \mathrm{a}, \mathrm{b}$ ), suggesting a tight coupling between electron transport and $\mathrm{CO}_{2}$ fixation. A second regulatory mechanism concerns the utilization of organic substrates in the presence of hydrogen. If the cells are exposed to fructose and hydrogen concomitantly, the utilization of fructose is suppressed and no growth occurs (Gottschalk, 1965; Blackkolb and Schlegel, 1968a). This " $\mathrm{H}_{2}$-effect" is due to the presence of hydrogenase as shown by experiments with hydrogenase-free mu- 
tants (Blackkolb, 1968). The molecular mechanism of both these phenomena has so far not been elucidated; it is not known which of both hydrogenases is involved (Schlegel and Eberhardt, 1972).

Pfitzner (1974) succeeded in isolating mutants of $A$. eutrophus each lacking only one of the two hydrogenases. He postulated genetic independence of both hydrogenases. The present work aimed at characterizing new mutants defective in autotrophic metabolism and at investigating the specific contribution of each hydrogenase to the metabolism and to the regulatory processes mentioned.

\section{Materials and Methods}

\section{Growth Conditions}

Alcaligenes eutrophus H 16 (Wilde, 1962) ATCC 17699, DSM 428 , was grown in a mineral medium according to Schlegel et al. (1961). For heterotrophic growth the organic substrates were added (acids as $\mathrm{Na}$-salts) to a concentration of $0.5 \%$ (acetate to $0.2 \%$ ). In the case of autotrophic growth, the atmosphere contained $80 \% \mathrm{H}_{2}, 10 \% \mathrm{O}_{2}$, and $10 \% \mathrm{CO}_{2}$. Liquid media were shaken in fluted Erlenmeyerflasks on a rotary shaker with 150 r.p.m. at $30^{\circ} \mathrm{C}$.

Besides the wild-type, the mutant strains $\mathrm{LH}^{-} 7$ and $\mathrm{PH}^{-} 9$ (Pfitzner, 1974), DSM 416 and DSM 418, lacking soluble or membrane-bound hydrogenase, were used for physiological characterization. The stability of these mutants was controlled by plating samples on autotrophic mineral agar plates. Cell densities were measured in $1 \mathrm{~cm}$ cuvettes against saline at $436 \mathrm{~nm}$ using a Zeiss photometer PL 4.

\section{Selection of Mutants}

Nitrous acid, ethyl methane sulphonate and $\mathrm{N}$-methyl- $\mathrm{N}^{\prime}$-nitro-Nnitroso-guanidine were used as mutagens. The experimental procedures were those described by Bowien and Schlegel (1972). After growth for phenotypic expression, the suspensions were diluted and plated on mineral plates containing $0.05 \% \mathrm{NaHCO}_{3}+0.005 \%$ fructose. After growth for 2 days under air and 3 days under a mixture of $\mathrm{H}_{2}+\mathrm{O}_{2}+\mathrm{CO}_{2}$ pinpoint colonies were picked. Differentiation from wild-type colonies occurred by replica plating on mineral media containing fructose, glucose or $\mathrm{NaHCO}_{3}$. A. eutrophus does not grow on glucose. Those colonies were selected which grew well on fructose, did not grow on glucose and not or only poorly under autotrophic conditions.

\section{Preparation of Cell-Free Extracts}

Cells were harvested at an optical density $(436 \mathrm{~nm})$ of $7-9$, washed and resuspended in $4 \mathrm{ml} 67 \mathrm{mM}$ potassium phosphate buffer, $\mathrm{pH} 7.0$, per gram wet weight. The suspension was stored at $-15^{\circ} \mathrm{C}$. The cells were disrupted in a French high pressure cell at about 1750 bar or by sonication (Schoeller TG 250, 600 W, $20 \mathrm{kHz}, 1 \mathrm{~min} / 10 \mathrm{ml}$ ), keeping the temperature of the suspension within $0-10^{\circ} \mathrm{C}$.

After removal of non-disrupted cells by centrifugation at $10000 \mathrm{~g}$ for $20 \mathrm{~min}$ (Christ Zeta 20) the membranes were separated from the cytoplasm by centrifugation at $100000 \mathrm{~g}$ for $90 \mathrm{~min}$ (Christ, Omikron). Membranes were resuspended in the same buffer. In both fractions NADH-oxidase and malate-dehydrogenase were tested.
Protein determination was carried out according to Schmidt et al. (1963) for whole cells, and after Beisenherz et al. (1953) for cellfree extracts, using calibration curves prepared with bovine serum albumine as a standard.

\section{Enzyme Assays}

All photometric measurements were carried out in $1 \mathrm{~cm}$ cuvettes at $365 \mathrm{~nm}$ and at $30^{\circ} \mathrm{C}$ in a Zeiss PL 4 photometer. The molar extinction coefficient for NADH of $3.2 \times 10^{6} \mathrm{~cm}^{2} / \mathrm{mol}$ was used for calculation. NADH oxidase and malate dehydrogenase were measured as described (Aggag and Schlegel, 1973). Hydrogen-dehydrogenase was measured with NAD as acceptor in potassium phosphate buffer at pH. 7.0 (Pfitzner et al., 1970).

For manometric experiments a Warburg apparatus (Braun, Melsungen) with a shaking-amplitude of $4 \mathrm{~cm}$ and 120 strokes per min was used. The reactions were observed at $30^{\circ} \mathrm{C}$ in intervals of $10 \mathrm{~min}$. Gas mixtures were purified by $20 \% \mathrm{KOH}$ or $20 \%$ alkaline pyrogallol. Details of methods for hydrogenase measurement of whole cells and of membrane fractions were those described by Eberhardt (1966).

Growth experiments were carried out in a thermoconstant water bath with a linear shaking apparatus of $4 \mathrm{~cm}$ amplitude and a frequency of $100 / \mathrm{min}$ at $30^{\circ} \mathrm{C}$. $30 \mathrm{ml}$ cell suspension in $200-\mathrm{ml}$ Erlenmeyer-flasks with gas in- and outlet were flushed by defined gas mixtures for $15 \mathrm{~min}$. Samples were taken by syringes; after sampling the gassing was repeated. Parallel samples were run under air.

Immunodiffusion was carried out according to the modified Ouchterlony test from Oakley (1971).

\section{Chemicals}

The biochemicals used were obtained from Fa. Boehringer, Mannheim: NAD, NADH, oxaloacetic acid; from Eastman Organic Chemicals, U.S.A.: EMS; from Serva, Heidelberg: MNG, agarose, bovine serum albumine; from Difco Laboratories, Detroit: peptone and agar. All other chemicals were obtained from Merck, Darmstadt.

\section{Results}

\section{Isolation of Mutants}

Using the pinpoint method, mutants were selected which grew poorly or not at all under autotrophic conditions; 44 such mutants were studied with respect to their specific hydrogenase activities. For this purpose mutants were grown heterotrophically on pyruvate; high activities of both the soluble and the membranebound hydrogenase were found in wild-type cell extracts after growth on this substrate. The mutants were arranged into five groups: a) 4 mutants with full activity of both hydrogenases possibly defective in an enzyme for $\mathrm{CO}_{2}$ fixation; b) 17 mutants without any hydrogenase activity; c) 1 mutant with only a particulate hydrogenase which had less specific activity than the wild-type; d) 7 mutants with only soluble hydrogenase which had less specific activity than the wildtype; e) 15 mutants with varying deficiencies in both enzymes. 
Table 1. Generation times and specific hydrogenase activities in wild-type and mutant strains of Alcaligenes eutrophus after autotrophic and heterotrophic growth

\begin{tabular}{|c|c|c|c|c|c|}
\hline \multirow[t]{3}{*}{ Strain } & \multirow{3}{*}{$\begin{array}{l}\text { Generation } \\
\text { time (h) } \\
\text { during } \\
\text { autotrophic } \\
\text { growth }\end{array}$} & \multicolumn{4}{|c|}{$\begin{array}{l}\text { Hydrogenase activity (units/g protein) } \\
\text { after growth on }\end{array}$} \\
\hline & & \multicolumn{2}{|l|}{$\mathrm{H}_{2} / \mathrm{O}_{2} / \mathrm{CO}_{2}$} & \multicolumn{2}{|l|}{ pyruvate } \\
\hline & & soluble enzyme & $\begin{array}{l}\text { membrane- } \\
\text { bound enzyme }\end{array}$ & soluble enzyme & $\begin{array}{l}\text { membrane- } \\
\text { bound enzyme }\end{array}$ \\
\hline M51 & & & & 0 & 0 \\
\hline $\mathrm{LH}^{-} 7$ & $10-11$ & 29 & 3050 & 0 & 78 \\
\hline $\mathrm{PH}^{-} 9$ & 3.5 & 412 & 12.3 & 112 & 8.6 \\
\hline N31 & & & & 231 & 297 \\
\hline Wild-type & 3.2 & 780 & 820 & 585 & 565 \\
\hline
\end{tabular}

\section{Characterization of Mutants}

For further physiological characterization the newly isolated mutants M 51 and N 31, as well as mutants $\mathrm{LH}^{-} 7$ and $\mathrm{PH}^{-} 9$ isolated by Pfitzner (1974) were chosen and compared to the wild-type. M51 and N31 could not grow autotrophically at all, $\mathrm{LH}^{-} 7$ grew only very slowly, whereas $\mathrm{PH}^{-} 9$ grew nearly as fast as the wild-type (Table 1). Heterotrophic growth of all mutants was unimpaired. In M51 no hydrogenase activity was detected, neither in the cytoplasm nor in the membrane fraction. In $\mathrm{LH}^{-} 7$ only the membranebound hydrogenase, in $\mathrm{PH}^{-9}$ only the soluble hydrogenase were functioning. In the mutant N31 both hydrogenases were unimpaired, however, both enzymes for autotrophic $\mathrm{CO}_{2}$ fixation, ribulose-5-phosphate kinase and ribulose-1,5-bisphosphate carboxylase were lacking. In the cell fractions of $\mathrm{LH}^{-} 7$ and $\mathrm{PH}^{-}$9, which lacked hydrogenase activity, the inactive enzyme could be detected in the form of crossreacting-material with antisera prepared against purified soluble or membrane-bound hydrogenase (Schink and Schlegel, in preparation). The lack of hydrogenase activity in these mutants was, therefore, not due to regulatory defects, but to alterations in the enzyme structure. In the mutant N 31 cross-reacting material of ribulose-5-phosphate kinase and ribulose1,5-bisphosphate carboxylase could not be detected (B. Bowien, personal communication). With cell fractions of mutant M 51 precipitin lines of cross-reacting material of both hydrogenases were detected, which were scarcely visible.

Reversion experiments with mutants M51 and N 31 resulted in rather low revertant frequency: $10^{-7}-$ $5 \times 10^{-8}$. M 51 revertants had regained both the soluble and the membrane-bound hydrogenase concomitantly, as shown by random tests of 16 revertant strains isolated. This indicates both mutants, M 51 and N 31, carrying regulatory mutations. With the mutants $\mathrm{PH}^{-} 9$ and $\mathrm{LH}^{-} 7$ determination of the reversion rate
Table 2. Rates of hydrogen oxidation by intact wild-type and mutant cells in the presence of different electron acceptors

\begin{tabular}{lccc}
\hline Strain & \multicolumn{2}{l}{ Electron acceptor } & \\
\cline { 2 - 4 } & $\mathrm{O}_{2}$ & $\begin{array}{l}\text { methylene } \\
\text { blue }\end{array}$ & $\begin{array}{l}\mathrm{O}_{2}+\text { meth- } \\
\text { ylene blue }\end{array}$ \\
\hline $\mathrm{M} 51$ & 0.30 & 0.05 & 0.36 \\
$\mathrm{LH}^{-7}$ & 16.5 & 20.5 & 24.7 \\
$\mathrm{PH}^{-9}$ & 4.3 & 9.7 & 11.9 \\
$\mathrm{~N}^{-31}$ & 3.45 & 5.5 & 7.8 \\
Wild-type & 9.1 & 18.0 & 24.2 \\
\hline
\end{tabular}

Mutants M51 and N31 were grown heterotrophically on pyruvate, the others under autotrophic conditions

Gas uptake was measured manometrically under hydrogen atmosphere with either $10 \% \mathrm{O}_{2}$ and/or with $10 \mu$ moles methylene blue as electron acceptors. Values represent $\mu \mathrm{l}$ gas $/ \mathrm{min} \times \operatorname{mg}$ protein

turned out to be impossible because of high background growth of the mutants under autotrophic conditions. In cell suspensions growing autotrophically, however, no indication for the return of the mutated enzyme could be detected.

Comparing the hydrogenase activities measured in pyruvate-grown cells (Table 1) it becomes obvious that the mutants $\mathrm{LH}^{-} 7$ and $\mathrm{PH}^{-} 9$ not only lacked one hydrogenase enzyme completely, but produced the remaining enzyme at a lower specific activity than the wild-type. After autotrophic growth the activity of the membrane-bound enzyme of $\mathrm{LH}^{-} 7$ was almost 4-fold higher than in the wild-type.

The hydrogen oxidation rates of intact cells are listed in Table 2. In any case the rates of gas uptake were higher in the presence of methylene blue (either alone or in the presence of oxygen) than with oxygen as the sole hydrogen acceptor. The oxidation of hydrogen by the particulate hydrogen oxidase system or by the soluble hydrogenase and NADH-oxidase was apparently lim- 
ited by the $\mathrm{O}_{2}$-terminal components of the respiratory chain (Wilde, 1962).

\section{Influence of Carbon Dioxide on Hydrogen Oxidation}

The availability of hydrogenase-deficient mutants prompted us to examine the role of either of the two hydrogenases in the "CO 2 -effect" (Schlegel and Bartha, $1961 \mathrm{a}, \mathrm{b}$ ). The rate of total gas uptake by whole cells was measured under an atmosphere of $\mathrm{H}_{2}$ and $\mathrm{O}_{2}$ in the absence and in the presence of $\mathrm{CO}_{2}$ (Table 3). From the rates measured under both conditions a quotient was calculated. Wild-type and mutant $\mathrm{PH}^{-} 9$ responded to the presence of $\mathrm{CO}_{2}$ by high increases of the $\mathrm{H}_{2}$-oxidation rate, while the mutants $\mathrm{LH}^{-} 7$ and N31 responded only by a negligibly small increase. From these results the conclusion is drawn that it is the soluble hydrogenase which is involved in the $\mathrm{CO}_{2}$ effect.

\section{Influence of Hydrogen on the Utilization of Fructose}

Experiments were designed to examine whether the suppression of fructose utilization by hydrogen is a result of the function of both hydrogenases or whether the suppression occurs in cells containing only a single hydrogenase, too. The mutant strains were incubated in growth medium in the presence of fructose either under air or under a $\mathrm{CO}_{2}$-free hydrogen and oxygen mixture. Except strain M51 all mutants and the wild-type were subject to a significant suppression of growth under the hydrogen-oxygen atmosphere. Therefore, it is not possible to attribute the suppressive effect specifically to one of both hydrogenases.

\section{Contributions of the Hydrogenases to Heterotrophic Growth on Pyruvate}

Growth on pyruvate is not repressed by hydrogen (Blackkolb and Schlegel, 1968a). The remarkably high activities of the hydrogenases after growth on pyruvate raised the question whether A.eutrophus $\mathrm{H} 16$ is able to use pyruvate and hydrogen concomitantly. Comparative growth experiments with limiting concentrations of pyruvate in the presence and absence of hydrogen were carried out. The most significant results were obtained using the experimental procedure of Rittenberg and Goodman (1969). A cell suspension precultivated autotrophically was supplemented by pyruvate and divided up into two flasks; one agitated under air, the other flask was exposed for $4 \mathrm{~h}$ to a gas mixture of $70 \% \mathrm{H}_{2}, 20 \% \mathrm{O}_{2}$, and $10 \% \mathrm{CO}_{2}$. A suspension without pyruvate under the gas mixture
Table 3. Influence of carbon dioxide on hydrogen-oxidation by intact autotrophically grown cells (mutant N31 was grown heterotrophically on pyruvate). Measurement of total gas uptake of wild-type and mutant cells in the presence or absence of $\mathrm{CO}_{2}(\mu \mathrm{I} \mathrm{gas} / \mathrm{min} \times \mathrm{mg}$ protein)

\begin{tabular}{lccl}
\hline Strain & \multicolumn{2}{l}{ Gas consumption } & $\begin{array}{l}\text { Quotient } \\
\text { with } \mathrm{CO}_{2}\end{array}$ \\
& with $\mathrm{CO}_{2}$ & without $\mathrm{CO}_{2}$ & $\begin{array}{l}\text { without } \mathrm{CO}_{2} \\
\end{array}$ \\
\hline $\mathrm{LH}^{-} 7$ & 20.4 & 16.5 & 1.24 \\
$\mathrm{PH}^{-9}$ & 14.1 & 4.3 & 3.3 \\
$\mathrm{~N}^{9}$ & 7.7 & 6.9 & 1.12 \\
Wild-type & 26.6 & 9.1 & 2.9 \\
\hline
\end{tabular}

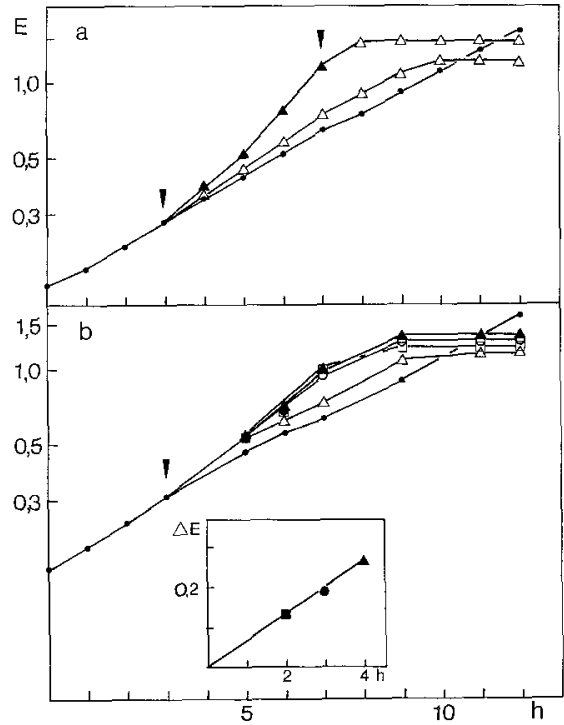

Fig.1. a Growth of Alcaligenes eutrophus H16 under autotrophic, heterotrophic and mixotrophic conditions. Symbols: (•) autotrophic growth under $70 \% \mathrm{H}_{2}+20 \% \mathrm{O}_{2}+10 \% \mathrm{CO}_{2} ;(\triangle)$ heterotrophic growth on $0.05 \%$ pyruvate under air; $(\mathbf{\Lambda})$ growth on $0.05 \%$ pyruvate, under $70 \% \mathrm{H}_{2}+20 \% \mathrm{O}_{2}+10 \% \mathrm{CO}_{2}$ for $4 \mathrm{~h}$. The first arrow marks the addition of pyruvate to $\mathrm{B}$ and $\mathrm{C}$; the second arrow indicates the replacement of the $\mathrm{H}_{2}+\mathrm{O}_{2}+\mathrm{CO}_{2}$ mixture by air in vessel $\mathrm{C}$. b Growth of $A$. eutrophus $\mathrm{H} 16$ in the presence of pyruvate and hydrogen gas mixture. Five replicate cultures started in autotrophic medium. Pyruvate was added after $3 \mathrm{~h}(\mathbf{\nabla})$. Air was substituted for hydrogen atmosphere after $0 \mathrm{~h}(\triangle), 2 \mathrm{~h}(\square), 3 \mathrm{~h}(\mathrm{O}), 4 \mathrm{~h}(\boldsymbol{\Delta})$. The closed circle marks the autotrophic control. The inset shows the correlation between growth increment and the duration of time hydrogen was present as an additional electron donor besides pyruvate

mentioned served as the autotrophic control. When the wild-type was grown on pyruvate in the presence of hydrogen, the growth rate increased faster than when growing on pyruvate alone; hydrogen was removed before the total exhaustion of pyruvate; the cell yields were significantly higher than in the vessel without hydrogen (Fig. 1 a). This difference in the cell yields was 


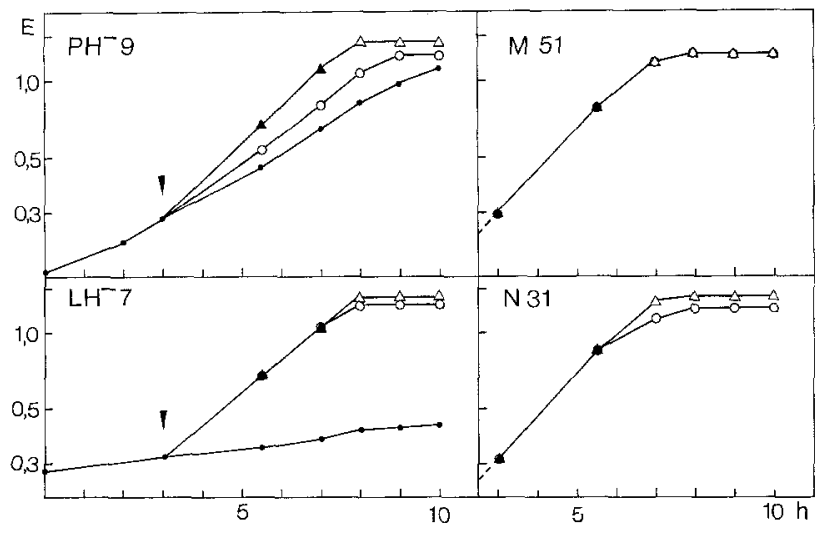

Fig. 2. Growth of mutant strains under autotrophic, heterotrophic and mixotrophic conditions. The arrow marks the addition of $0.05 \%$ pyruvate. Hydrogen was given for $4 \mathrm{~h}$ or, with $\mathrm{N} 31$, for $3 \mathrm{~h}$. Symbols: Autotrophic growth under $70 \% \mathrm{H}_{2}+20 \% \mathrm{O}_{2}+10 \% \mathrm{CO}_{2}(\bullet)$ growth on pyruvate under air $(\mathrm{O})$; growth on pyruvate under $70 \% \mathrm{H}_{2}$ $+20 \% \mathrm{O}_{2}+10 \% \mathrm{CO}_{2}$ for $4 \mathrm{~h}$ (with $\mathrm{N} 31$ for $3 \mathrm{~h}$ ) (ム). Open triangles indicate the values measured after replacement of hydrogen gas mixture by air

a linear function of the time during which hydrogen was supplied (Fig. 1 b), suggesting that the autotrophic and the heterotrophic substrate were used concomitantly as long as both substrates were present. Comparative studies with the different mutant strains lead to the following results (Fig. 2): when the mutant M 51, which cannot use hydrogen at all, was grown on pyruvate in the presence and absence of hydrogen, the growth rate and the cell yield were identical. Mutant M31 precultivated on pyruvate had the same growth rate, but there was a difference in the cell yields after growth in the presence and in the absence of hydrogen. This difference was somewhat smaller than the difference observed with the wild-type; this observation is in accordance with the lower hydrogenase activities of the mutant. The behaviour of the mutant $\mathrm{PH}^{-} 9$ was nearly identical to that of the wild-type, but the difference in the cell yield was smaller. Mutant $\mathrm{LH}^{-} 7$ behaved in a similar manner, however, in the presence and absence of hydrogen the growth rates were identical; this corresponds to the rather low autotrophic growth rate of this mutant.

\section{Discussion}

\section{Relationships between Both Hydrogenases}

Four types of mutants deficient in autotrophic metabolism have been described in this paper; in three of these mutants, the hydrogenases were concerned. The study pertained to the relationship between both the hydrogenases, as well as to the different roles these enzymes play in metabolism. The mutant N 31 defective in $\mathrm{CO}_{2}$ fixation was studied for comparison. Among the mutants isolated, those lacking or being defective in both hydrogenases predominated. This may be due to the method of mutant selection; differentiation between the wild-type and mutants lacking the membrane-bound hydrogenase by inspection of colony size on agar plates is difficult. The predominance of double-defective mutants might be explained by a hypothetical subunit common to both hydrogenases; however, biochemical and immunological tests did not provide any evidence (Schink and Schlegel, in preparation). Rather, regulatory relationships exist between both hydrogenases: when hydrogenase activities were measured in the wild-type cells harvested in different growth phases and when growing on different substrates, in every instance the activities of both enzymes were found to vary in a parallel manner. These results are in agreement with the findings of Eberhardt (1966) and Frings (1969); they contrast to some previous observations (Pfitzner et al., 1970). The regulation of both enzymes is apparently connected; the structural genes may be closely linked and the double-defective mutant M 51 may be of the polarity type. The relatively low activity of the hydrogenase still functioning in the mutants defective in only one hydrogenase is indicative for polarity mutants, too.

\section{Functions of Both Hydrogenases in Metabolism}

The majority of hydrogen bacteria contain only a membrane-bound hydrogenase which does not reduce NAD. In Alcaligenes eutrophus each hydrogenase enzyme apparently has a specific function. The membrane-bound hydrogenase provides electrons for the respiratory chain and the supply of ATP (Probst and Schlegel, 1976), whereas the soluble hydrogenase regenerates $\mathrm{NADH}$ required for the autotrophic $\mathrm{CO}_{2}$ fixation (Schneider and Schlegel, 1976). NADH can also be fed into the electron transport chain (Pfitzner, 1969).

The experiments described in this paper confirm the conclusion that A. eutrophus H16 can grow autotrophically with only one of the two enzymes (Pfitzner, 1974). Neither of the two enzymes is essential for growth as long as the alternate enzyme is present; each one may compensate for the loss of the other. The cell apparently can easily dispense with the membrane-bound enzyme; its absence is evidently fully compensated by the function of the soluble hydrogenase and the NADH oxidase system. In the reverse case, if only the membrane-bound enzyme is present, the rate of autotrophic growth is markedly decreased; this is in agree- 
ment with an assumed energy consuming reverse electron transport flow serving NADH regeneration.

Both hydrogenases can contribute to heterotrophic growth. Autotrophically grown wild-type cells supplied by a limiting amount of pyruvate reach a higher cell yield in the presence of hydrogen than in its absence. The experiments indicate that the autotrophic and the heterotrophic substrate were utilized concomitantly as long as both were available to the cells. These observations agree with those of Rittenberg and Goodman (1969) who described mixotrophic growth of $\mathrm{A}$.eutrophus on lactate and a hydrogen-oxygen-carbon dioxide mixture. Comparing the growth yields of our mutants under these conditions leads to the conclusion that it was the hydrogen and the electrons derived therefrom, respectively, which limited the cell yield: the mutant M51 lacking both hydrogenases showed no difference in the cell yield, whereas mutant N31 lacking functioning $\mathrm{CO}_{2}$ fixation, however, containing both hydrogenases reached an increased cell yield in the presence of hydrogen. These additional electrons are provided at a more favourable potential by the soluble hydrogenase compared to the membrane-bound hydrogenase, as reflected by a higher yield difference obtained by mutant $\mathrm{PH}^{-} 9$ than that obtained by $\mathrm{LH}^{-} 7$. Whether carbon dioxide is actually fixed by the wild-type, when both substrates are present, has to be examined by labelling experiments.

\section{Involvement of Hydrogenases in the Regulation of Metabolism}

The rate of uptake of the hydrogen-oxygen mixture is 3-4 times higher in the presence of carbon dioxide than in its absence (Schlegel and Bartha, 1961 a, b). This carbon dioxide enhancement effect suggested a tight coupling between electron transport and the regeneration of ATP from the ADP resulting from energy consuming autotrophic $\mathrm{CO}_{2}$ fixation. No carbon dioxide effect was observed in the mutants N31 and $\mathrm{LH}^{-} 7$, but the $\mathrm{CO}_{2}$-effect was pronounced in $\mathrm{PH}^{-} 9$. These observations confirm conclusions drawn from the comparison of wild-type species. The $\mathrm{CO}_{2}-$ enhancement effect was encountered only in strains containing a soluble hydrogenase, such as Alcaligenes eutrophus H1, H16, H20 (Bartha, 1962) and A. eutrophus (Bongers, 1970) and not encountered in strains containing only a membrane-bound hydrogenase (Eberhardt, 1966, 1969; Schneider et al., 1973).

The suppression of the utilization of and growth on some organic substrates such as fructose, gluconate or acetate by gaseous hydrogen has been observed only in hydrogenase containing wild-type cells. Hydrogen represses the formation of the enzymes of the Entner-
Doudoroff pathway and in addition, inhibits the degradation of fructose via the enzymes present. This inhibitory effect has been localized in glucose-6phosphate dehydrogenase being inhibited by NADH and ATP (Blackkolb and Schlegel, 1968b) in vitro. Transition experiments and pool-size measurements indicated NADH to be the effective inhibitor (Bowien et al., 1974). The results obtained in this study do not allow to attribute the suppressive effect exerted by hydrogen to one single hydrogenase. The function of either one of both enzymes proved to be effective.

Acknowledgements. The authors are greatly indebted to Miss M. Meyer for her skilful technical assistance in some experiments. We are grateful to Dr. B. Bowien for measuring ribulose-5-phosphate kinase and ribulose-1,5-bisphosphate carboxylase and to Dr. B. Friedrich and Dr. D. Wilke for discussions.

\section{References}

Aggag, M., Schlegel, H. G.: Studies on a Gram-positive hydrogen bacterium Nocardia opaca strain 1b. I. Description and physiological characterization. Arch. Mikrobiol. 88, 299-318 (1973)

Aggag, M., Schlegel, H. G.: Studies on a Gram-positive hydrogen bacterium, Nocardia opaca 1b. III. Purification, stability and some properties of the soluble hydrogen dehydrogenase. Arch. Microbiol. 100, 25-39 (1974)

Atkinson, D. E., McFadden, B.: The biochemistry of Hydrogenomonas. I. The hydrogenase of Hydrogenomonas facilis in cellfree preparations. J. Biol. Chem. 210, $885-893$ (1954)

Bartha, R.: Physiologische Untersuchungen über den chemolithotrophen Stoffwechsel neu isolierter Hydrogenomonas-Stämme. Arch. Mikrobiol. 41, 313-350 (1962)

Beisenherz, G., Bolze, H. J., Bücher, T., Czok, R., Garbade, H. K., Meyer-Arendt, E., Pfleiderer, G.: Diphosphofructose-Aldolase, Phosphoglyceraldehyde-Dehydrogenase, Milchsäure-Dehydrogenase, Glycerophosphat-Dehydrogenase und Pyruvat-Kinase aus Kaninchenmuskulatur in einem Arbeitsgang. Z. Naturforsch. Teil B, 8, 555-577 (1953)

Blackkolb, F.: Zur Regulation des ED-Abbauweges in Hydrogenomonas durch molekularen Wasserstoff. Ph.D. Thesis, Univ. Göttingen (1968)

Blackkolb, F., Schlegel, H. G.: Katabolische Repression und Enzymhemmung durch molekularen Wasserstoff bei Hydrogenomonas. Arch. Mikrobiol. 62, 129-143 (1968a)

Blackkolb, F., Schlegel, H. G.: Regulation der Glucose-6-phosphatDehydrogenase aus Hydrogenomonas $\mathrm{H} 16$ durch ATP und $\mathrm{NADH}_{2}$. Arch. Mikrobiol. 63, 177-196 (1968b)

Bone, D. H., Bernstein, S., Vishniac, W.: Purification and some properties of different forms of hydrogen dehydrogenase. Biochim. Biophys. Acta 67, 581-588 (1963)

Bongers, L.: Energy generation and utilization in hydrogen bacteria. J. Bacteriol. 104, 145-151 (1970)

Bowien, B., Cook, A. M., Schlegel, H. G.: Evidence for the in vivo regulation of glucose 6-phosphate dehydrogenase activity in Hydrogenomonas eutropha $\mathrm{H} 16$ from measurements of the intracellular concentrations of metabolic intermediates. Arch. Microbiol. 97, 273-281 (1974)

Bowien, B., Schlegel, H. G.: Isolierung und Charakterisierung katabolischer Defektmutanten von Hydrogenomonas eutropha Stamm H16. I. Fructose-negative Mutanten. Arch. Mikrobiol. $87,203-219(1972)$ 
Eberhardt, U.: Über das Wasserstoff aktivierende System von Hydrogenomonas H16. I. Verteilung der Hydrogenase-Aktivität auf zwei Zellfraktionen. Arch. Mikrobiol. 53, 288-302 (1966)

Eberhardt, U.: On chemolithotrophy and hydrogenase of a Grampositive Knallgas bacterium. Arch. Mikrobiol. 66, 91-104 (1969)

Ecker, C.: Nachweis der plasmidgebundenen, autotrophes Wachstum ermöglichenden Enzyme bei Nocardia. Ph.D. Thesis, Univ. Göttingen (1977)

Frings, W.: An der heterotrophen $\mathrm{CO}_{2}$-Fixierung von Hydrogenomonas $\mathrm{H} 16$ beteiligte Reaktionen. Ph.D. Thesis, Univ. Göttingen (1969)

Gottschalk, G.: Die Verwertung organischer Substrate durch Hydrogenomonas in Gegenwart von molekularem Wasserstoff. Biochem. Z. 341, 260-270 (1965)

Ishaque, M., Aleem, M. J. H.: Energy coupling in Hydrogenomonas eutropha. Biochim. Biophys. Acta 223, 388-397 (1970)

Kühnemund, H.: Zur Verwertung von molekularem Wasserstoff durch Micrococcus denitrificans. Ph. D. Thesis, Univ. Göttingen (1971)

Oakley, C. L.: Antigen-antibody reactions in microbiology. In: Methods in microbiology, Vol. 5A (J. R. Norris, D. W. Ribbons, eds.), pp. 173-218. London-New York: Academic Press 1971

Pfitzner, J.: Die NAD-spezifische Hydrogenase und das Elektronentransportsystem von Hydrogenomonas $\mathrm{H} 16$. Ph. D. Thesis, Univ. Göttingen (1969)

Pfitzner, J.: Ein Beitrag zum $\mathrm{H}_{2}-\mathrm{O}_{2}$-Oxidoreduktasesystem von Hydrogenomonas eutropha Stamm H16: Hydrogenasedefekte Mutanten. Zentralbl. Bakteriol. Parasitenkd. Infektionskr. Hyg. Abt. 1, Orig. Reihe A 228, 121-127 (1974)

Pfitzner, J., Linke, H. A. B., Schlegel, H. G.: Eigenschaften der NAD-spezifischen Hydrogenase aus Hydrogenomonas H16. Arch. Mikrobiol. 71, 67-78 (1970)

Probst, I., Schlegel, H. G.: Respiratory components and oxidase activities in Alcaligenes eutrophus. Biochim. Biophys. Acta 440, $412-428$ (1976)

Rittenberg, S. C., Goodman, N. S.: Mixotrophic growth of Hydrogenomonas eutropha. J. Bacteriol. 98, 617-622 (1969)
Schlegel, H. G., Bartha, R.: „Leerlauf“- $\mathrm{H}_{2}$-Oxidation und „,Rückkoppelung" bei Knallgasbakterien. Naturwissenschaften $\mathbf{4 8}$, 414 (1961 a)

Schlegel, H. G., Bartha, R.: Hemmungsanalytische Versuche zum Rückkoppelungseffekt bei Hydrogenomonas. Z. Naturforsch. Teil B, 16, 777- 780 (1961 b)

Schlegel, H. G., Eberhardt, U.: Regulatory phenomena in the metabolism of Knallgasbacteria. Adv. Microb. Physiol. 7, 205242 (1972)

Schlegel, H. G., Kaltwasser, H., Gottschalk, G. : Ein Submersverfahren zur Kultur wasserstoffoxidierender Bakterien: Wachstumsphysiologische Untersuchungen. Arch. Mikrobiol. 38, $209-222$ (1961)

Schmidt, K., Liaaen-Jensen, S., Schlegel, H. G.: Die Carotinoide der Thiorhodaceae. I. Okenon als Hauptcarotinoid von Chromatium okenii Perty. Arch. Mikrobiol. 46, 117-126 (1963)

Schneider, K., Rudolph, V., Schlegel, H. G.: Description and physiological characterization of a coryneform hydrogen bacterium, strain 14g. Arch. Mikrobiol. 93, 179-193 (1973)

Schneider, K., Schlegel, H. G.: Purification and properties of soluble hydrogenase of Alcaligenes eutrophus H16. Biochim. Biophys. Acta 452, 66-80 (1976)

Schneider, K., Schlegel, H. G.: Localization and stability of hydrogenases from aerobic hydrogen bacteria. Arch. Microbiol. 112, 229-238 (1977)

Vishniac, W., Trudinger, P. A.: Carbon dioxide fixation and substrate oxidation in the chemosynthetic sulfur and hydrogen bacteria. Bacteriol. Rev. 26, 168-175 (1962)

Wilde, E.: Untersuchungen über Wachstum und Speicherstoffsynthese von Hydrogenomonas. Arch. Mikrobiol. 43, 109-137 (1962)

Wittenberger, C. L., Repaske, R.: Studies on hydrogen oxidation in cell-free extracts of Hydrogenomonas eutropha. Biochim. Biophys. Acta 47, 542-552 (1961)

Received December 2, 1977 